\title{
Peculiarities of using creative neologisms in publicistic texts
}

\author{
Olga A. Kalugina - Dinara G. Vasbieva - Roza A. Valeeva - Elena V. \\ Maystrovich - Olga V. Pashanova
}

DOI: 10.18355/XL.2019.12.04.10

\begin{abstract}
Creative neologisms are a strategic unit of communication, increasing the importance of modern publistic texts. The paper aims to consider the phenomenon of creative neologisms by the example of text fragments of English-language newspapers and to implement an adequate classification of creative neologisms. The relevance of studying creative neologisms in modern publicistic texts is due to the fact that they can be considered as the linguistic and discursive potential of a publicistic text. The methodological basis for the research comprises method of linguistic-stylistic analysis based on Sánchez's typology (2016) of the creative neologisms according to their construction devices. The findings suggest that the potential of using creative neologisms in the publicistic texts is high though the percentage of literary creative devices is rather unstable as compared with the formal ones. Although the corpus study is not very big, this trend is quite visible. The experiment has also shown that the level of students' awareness of literary creative devices that are less frequently used in the publicistic texts is high and can be explained by the differences in perception of creative neologisms by the writers and readers, though this assumption requires further research.
\end{abstract}

Key words: creative neologism, occasional word, neologism, word-formation process, Sánchez's typology

\section{Introduction}

The modern world is characterized by an increase in the number of discoveries in various fields of human activity, which serves as a strong incentive for the enrichment and expansion of the vocabulary of most languages. Most scientists share the opinion that the number of words increases during the development of new technology. Technological advances have had a huge impact on society since the second half of the 20th century. However, enrichment of the English vocabulary is facilitated by the appearance of not only new electronic gadgets but also new phenomena, a change in lifestyle, political situations, and technical equipment of living conditions. The coinage of new words and concepts that reflect the realities of life is the result of a direct reflection of technological progress in the language.

The rapid development of new information and communication technology along with significant changes in science, economy, and communications, as well as the expansion of intercultural interaction, are the main factors influencing the changes in the English dictionary.

Language is constantly changing, evolving, and adapting to the needs of its users. Every year, new words are being coined, and new meanings added to already existing words. Such words are usually referred to as neologisms, which are characterized by different time span and frequency of usage (Raitskaya, 2007: 95). According to the explanatory dictionary of the Russian language edited by Ushakov (1935-1940), "neologism is a word that has reappeared in the language, an old word with a completely new meaning. While Shchukin's linguodidactic encyclopedic dictionary (2007: 175) gives the meaning of the word "neologism" as "a word or a turn of speech created to indicate a new subject or expression of a new concept." Neologisms constantly appear in the language as a natural part of language evolution.

XLinguae, Volume 12, Issue 4, October 2019, ISSN 1337-8384, eISSN 2453-711X 
Working with language evolution is part of learning a foreign language. And working with unknown vocabulary is the number one step that will help to cope with words that have not been found yet in the dictionary.

Modern language experts pay great attention to the creative potential of the language. The study of creative linguistic capabilities allows us to expand our understanding of the linguistic system, existing laws, and non-systemic phenomena. Today, undoubtedly, the most productive sources of research in this direction include publicistic writing. Strengthening the person's principle, focusing on attracting a readership leads to an expansion of the set of expressive means used in publicistic writing. Publicists include the word-formation of the language in their methods, actively creating new words, creative neologisms. Placed in the text of newspaper articles, they become one of the most striking expressive techniques of modern publicists.

The relevance of the topic is determined by the insufficient knowledge of the specifics of word-formation processes in creative neologisms. Moreover, in a publicistic text, creative neologisms are becoming more and more frequent. Today the research into this type of neologisms is done in various directions: lexicographical, word-formation, stylistic, and sociolinguistic. Language experts are more focused on the wordformation processes in creative neologisms. However, most researchers pay attention only to the formal side of the formation of creative neologisms and the description of their structure in isolation from the substantive aspect of word production. A comprehensive approach to the description of creative neologisms functioning in the media texts is required, which will reveal the deep-seated potentials of the wordformation process of the English language.

The subject matter of the present study is the creative neologisms used by publicists in the publicistic texts of English newspapers.

The scope of the study is the specifics of word-formation and functional features of creative neologisms used in publicistic texts of English newspapers.

The purpose of the research is to identify the features of word formation and specifics of creative neologisms functioning in publicistic texts and to raise awareness of the existence of creative neologisms in the given texts.

The present study was designed to:

- review the typology of methods for the formation of creative neologisms proposed by Sánchez (2016)

- study the issue of word-formation processes in creative neologisms in the articles of English newspapers

- identify the functions that perform creative neologisms used in publicistic texts

- identify the specifics of the functioning and perception of creative neologisms contained in publicistic texts through an experiment.

\section{Literature Review}

The cultural situation of the 21 st century implies free circulation of linguistic reality, encourages linguistic experiments, and manifests an expansion of interests in the field of creative possibilities of the language. The noted linguistic tendencies of the time are realized in creative neologism - word creation. The focus of neoplasms in our time is publicistic writing, in which the author's lexical findings are perceived, especially vividly as expressive means that enhance the expression of the speech. The abundance of individually-copyrighted neoplasms in the press is due to the specifics of modern journalism, namely, the process of its democratization, liberalization (Kostomarov, 1994).

The variety of approaches and lack of terminological and conceptual consensus among theorists make it difficult to provide a comprehensive definition of "creative 
neologism" that suits every possible taste. This confusion has led scientists to propose their definition, suitable for their studies.

Creative neologisms were the subject of study by linguistic scholars in the middle of the 20th century. For the first time, the term "occasional word" was used in the article by Feldman (1957), "Occasional Words and Lexicography." Feldman (1957), by creative neologism means "... a word formed by a linguistic inefficient or unproductive model, as well as by an occasional (speech) model and created for a specific case, either for everyday communication or for artistic purposes. Like a potential word, an occasional word is a fact of speech, not language."

According to Vinogradov's definition (2004), a creative neologism is "expressive, created by a specific author, generated by the goals of the utterance and the context with which they are connected and which are usually not reproduced devoid of context."

All complex occasional lexical items serve for a succinct communication of additional information about the subject of the speech, preventing writers from the need to use complex descriptive constructions and thereby making the utterance complex. The tendency of the modern language system to compression is confirmed by the prevalence of multicomponent syntactic occasional complex words (Gavrikova \& Dement'eva, 2017).

In the "Dictionary of linguistic terms" Akhmanova (2004) gives the following definition: "Occasional (word, meaning, phrase, sound combination, syntactic constitution) is "not normal"; it does not correspond to generally accepted use; characterized by individual taste, due to the specific context of use."

Popova (2005) clarifies this term by pointing out that "A creative neologism is a "onetime-use" lexical unit, devoid of reproducibility, and hence the historical duration of its existence, this word is not able to become obsolete, while the concept of neologism is opposed to the concept of archaism. It is due to entry into the language, and therefore due to its inclusion in historical life, the word that has arisen becomes neologism."

Radbil (2006) defining creative neologism as "anomalies of word-formation," believes that "the study of various kinds of violations and deviations from the known patterns of the language functioning allows us to better understand both the nature of the object itself and the level of knowledge about it."

Krysin (2008) narrows the definition of "a kind of neologism: a word formed to a given case, to this context."

Selivanova (2010) explains the term "creative neologism" this way: "Language units, which belong to the composition of stylistic neologisms, are composed in the idiostyle of certain authors' writing and are not widespread. Creative neologism emphasizes the individual author's language, give expressiveness, emotive coloring, ... is often created by non-traditional models of word formation and with violation of linguistic norms."

Creative neologism in Samylicheva's study (2011) is understood as new expressive words with inherent and becoming obvious in the context of adherent expressiveness, created in the process of speech, existing only in a specific context that generated them and not recorded in lexicographic sources.

In Komleva's study (2013), creative neologisms are defined as lexical units that are not fixed in defining dictionaries, existing within a specific context, and created by the authors both in productive and in unproductive and occasional word-formation models.

Thus the above definitions identified various characteristics of creative neologisms that allow them to be defined as independent word classes:

- "timeless" novelty inherent in creative neologism (Feldman, 1957)

- belonging to a specific context, the impossibility of functioning devoid of it (Feldman, 1957; Zemskaya, 1972; Vinogradov, 2004; Yurchenko, 2005)

XLinguae, Volume 12, Issue 4, October 2019, ISSN 1337-8384, eISSN 2453-711X 
- the probabilistic nature of the lexical meaning, which is specified by context (Komleva, 2013)

- non-normativity (Zemskaya, 1992).

Many national and foreign linguists are engaged in the study of creative neologism, in particular, their word-formation construction, which is important translating into other languages. Understanding connotative meanings and preserving them in the text of the translation allows us to reveal the creative possibilities of various languages and explore the successful discoveries of translators.

Belkova (2018) presents the following reasons encouraging authors to create individual authors' formations: the need for a more accurate expression of thought; expression of thought in a concise way; the need of the author to emphasize the attitude to the subject of speech, to give his/her characteristics, assessment; the desire to draw attention to its semantics; to avoid tautology; the need to maintain the rhythm of the verse, to provide rhyme.

The difficulty of translating creative neologism to another language, from the point of view of interlinguistic communication, lies in the absence of its equivalent in the target language, and the main problem in translating creative neologism to another language will be the need to convey its "cultural background."

It is advised to translate creative neologism employing language constructions existing in target-language or to invent one's new creative neologism and describe it in the footnotes. This process is highly creative, and there is no information about cases of its automatization (Shapochkin \& Butenko, 2011). Dzhabrailova and Kalashnikova (2018) concluded that the most effective ways of translating creative neologisms into the Russian language are replication, grammatical replacements, and modulation.

According to Klamer and Leonard (1994:27), "figurative speech, especially metaphor, allows us to comprehend in ways that literal rendering cannot." Furthermore, from a pragmatic point of view, when considering the significance of the sociological component in economic discourse, linguistic creativity can be seen as a tool that favors euphemistic language and linguistic courtesy as well as "re-enforcing intimacy between group members" (Zawada, 2005:42). Eventually, the publicistic style of writing especially in economic articles has a susceptibility to creative linguistic devices, such as wordplays, in order to capture the reader's attention.

Verdegal (2003) uses the concept of "creative neologism" (in Spanish, neologismo creativo) to refer precisely to this sort of phenomenon (even if he only considers tropes to be neological devices) in literary and advertising texts.

In this study, we use the term "creative neologism" to refer to the lexical phenomenon as the word-formation process in the given term includes a creative device.

\section{Methodology}

In accordance with our research objectives, the following research methods were used: the method of solid sample material, the method of analysis and synthesis, comparative method, method of linguistic-stylistic analysis based on Sánchez's typology (2016) of the creative neologisms according to their construction devices.

This study has undergone three stages:

- Identification and extraction of creative neologisms from publicistic texts

- Review and analysis of word-formation processes in creative neologisms through the typology proposed by Sánchez (2016)

-The experiment carried out to find out which devices from Sánchez's typology of creative neologisms helped identify creative neologisms in publicistic texts by the students.

Sánchez classified creative neologisms according to the types of two creative devices: literary and formal.

Creative neologisms formed through literary devices are as follows: 
- personified neologisms (attribution of human qualities to inanimate or abstract objects): silly season, smart bomb. Silly season is a period such as late summer when the mass media often focus on trivial of frivolous matters for lack of major news stories (Merriam-Webster, 2019). Example: As we enter «silly season» the summer months can provide much amusement for local newspaper readers. As part of a new Guardian Witness assignment looking at the local news in your area, we want to see the best silly season stories (The Guardian, Jul $18^{\text {th }}, 2013$ ). Smart bomb (Kadoch, 2013) is a bomb that is directed to the object it is intended to hit by a television signal or a laser (Cambridge Dictionary, 2019). Example: The US and Britain have said they will use more smart bombs if they attack again, and the Tornado has more advanced electronics and a greater ability to peer through the fog of war (The Guardian, Feb $\left.27^{\text {th }}, 2003\right)$.

- paronomasic neologisms (phonetic wordplay between words with same sounds and different meanings): Dream Team is a group of people who have been specially chosen to work together, and are considered to be the best at what they do (Cambridge Dictionary, 2019). Example: Ms Hewland, who makes Dream Team through her independent production company, Hewland International, added that she had probably made a mistake by killing off a lot of characters at the beginning of the current series, which had led to a collapse in ratings (The Guardian, Apr $26^{\text {th }}, 2006$ ).

- metonymic neologisms (replacement of a given object denomination by means of one of its qualities): Stockholm syndrome, Arab spring. Stockholm syndrome is the situation when a person who has been taken prisoner starts to like or trust the person or people who have taken them (Cambridge Dictionary, 2019). Example: Sarah \& Duck has kidnapped my heart - call it Stockholm syndrome if you will (The Guardian, Oct $18^{\text {th }}, 2019$ ). Arab spring is a series of anti-government uprisings affecting Arab countries of North Africa and the Middle East beginning in 2010 (Merriam-Webster, 2010). Example: Will corruption, cuts, and protest produce a new Arab spring? (The Guardian, Jan $26^{\text {th }}, 2019$ ).

- metaphoric neologisms (description of an element in terms of another, due to a relation of similarity between both of them): green shoots are any sign of growth and improvement (Macmillan Dictionary, 2019). Example: Baroness Vadera, the business minister, was widely ridiculed in January for suggesting that there were signs of "green shoots" of economic recovery (The Independent, March $25^{\text {th }}, 2009$ ).

- oxymoron neologisms (the juxtaposition of elements that appear to be contradictory): creative destruction, open secret. Creative destruction is described as the dismantling of long-standing practices in order to make way for innovation (Investopedia, 2019). Example: It was certainly easier to subscribe to creative destruction when its impacts were gradual and manageable; when its effects were conceptual and procedural (The Guardian, Oct $16^{\text {th }}, 2015$ ). Open secret is something that should be secret but is not because a lot of people know about it (Macmillan Dictionary, 2019). Example: Carlos Gamerro tackles this difficult subject in his novel, An Open Secret, by focusing on the disappearance in 1977 of one young man in a small town (The Independent, Nov $4^{\text {th }}, 2011$ ).

- physical-synesthetic neologisms (attribution of physical or material qualities to an abstract or ethereal reality: corrosive inequality is the destructive, unfair situation in society when some people have more opportunities, money, etc. than other people (Macmillan Dictionary, 2019). Example: Pakistan's corrosive inequality (The Guardian, Aug $\left.4^{\text {th }}, 2010\right)$.

- image neologisms (evocative representation of reality by means of another, due to a relation of similarity between both of them (in this case, both the imaginary and the real object are present within the term)): sandwich generation, balloon payment. Sandwich generation is the generation of people who care for their parents as well as

XLinguae, Volume 12, Issue 4, October 2019, ISSN 1337-8384, eISSN 2453-711X 
support their own children (Macmillan Dictionary, 2010). Example: Caught between an aging population and becoming a parent later in life, the "sandwich generation" has been overlooked for years (The Independent, Jan $18^{\text {th }}$ 2019). The balloon payment is the final large sum of money paid at the end of a loan period (Cambridge Dictionary, 2019). Example: At the end of the PCP contract, customers have the option to make a pre-agreed balloon payment or hand the keys back to the dealer and walk away (The Guardian, Sep $19^{\text {th }}, 2017$ ).

- peregrinism neologisms (based on linguistic elements borrowed from another language): teenage angst, ersatz religion. Teenage angst - teenagers who either make up their own drama inside of their heads or actually go through tough times (Urban dictionary, 2018). Twice as many girls are suffering "teenage angst" as boys, according to research that suggests growing up in Britain is toughest on young women (The Guardian, Apr $\left.17^{\text {th }}, 2011\right)$. Ersatz religion - substitute religion. Example: Capitalism may look like a cheap ersatz religion, but its consequences are far worse than the spectacle of fake fetishes (The Guardian, Jan $26^{\text {th }}, 2012$ ).

Creative neologisms formed through formal devices are as follows:

- hyphenated neologisms (chains of smaller lexical units connected with hyphens): too-big-to-fail - colloquialism centers around the idea that some businesses, such as the biggest banks, would cause widespread damage to the economy if they went bankrupt. To avoid a crisis, the government will intervene in the situation by providing bailout funds that support failing businesses, protecting companies from their creditors, and also protecting creditors against losses. Example: So banks are too big to fail. Are they also too big to regulate? (The Guardian, Nov $28^{\text {th }}, 2014$ ).

- clipping neologisms (removal of a prefix or suffix (or both) from an existing word and leaving an infix: self-cert mortgage is a type of mortgage that enabled individuals to borrow without having to prove their income. Example: Self-cert mortgages - dubbed "liar loans" - were aimed at self-employed workers who had trouble proving their income to lenders. They were hugely popular before the credit crisis and hugely controversial, amid evidence that many firms let borrowers inflate their salaries to obtain bigger home loans (The Guardian, Jan $20^{\text {th }}, 2016$ ).

- acronym neologisms (the combination of two or more initial components (individual letters or parts) of words that are pronounced as a single word): An IOU, otherwise known as an "I Owe You," is a document that acknowledges a debt owed. Example: From its politics to its economy to its environment and way of life, California is like a patient on life support. At the start of summer, the state government was so deeply in debt that it began to issue IOUs instead of wages (The Guardian, Oct $\left.4^{\text {th }}, 2009\right)$.

- blending neologisms (the combination of two or more lexemes from existing words): europhoria (blend of Europe + euphoria) - positive feelings about European integration (https://en.wiktionary.org/wiki/Wiktionary:Main_Page). Example: Italian europhoria may well undergo its sternest test when the changeover hassles of decimal points, mental arithmetic, and queues at vending machines start in just over two weeks (The Guardian, Dec $16^{\text {th }}, 2001$ ).

- morphological imitative neologisms (addition of morphemes like prefixes or suffixes to a given lexeme): crisiologist is a specialist on the crisis. Example: But this requires the crisiologist to locate crises in a precise theoretical framework in order to develop a general theory of crisis and corresponding praxis of crisis management (Jessop \& Knio, 2018).

\section{Results and Discussion}

The sources of the study were informational and analytical articles of the following newspapers: The Guardian (2000 - 2019) and The Independent (2000 - 2019). The 
choice of print media data as sources is due to the diversity of thematic focus. These newspapers cover current global events in the political, economic, and cultural spheres. The materials placed in them are diverse in genre and language structure. Journalists or publicists use all possible means of expression, actively forming creative neologisms through different devices.

A total of 69 creative neologisms were analyzed. For a detailed description and inclusion in the text of the study, creative neologisms were selected that correspond to the definition of a given linguistic phenomenon chosen by the authors, that is, possessing a certain "unusual" form (which can appear at different levels), not fixed in explanatory dictionaries and existing within a specific context.

Seventy-five Russian speaking full-time students studying Social Sciences took part in the study. The participants were given English language newspapers such as The Guardian and The Independent to find out which devices from Sánchez's typology of creative neologisms helped them identify creative neologisms in the publicistic texts.

Table 1: Proportion of creative devices in the publicistic texts involved in the experiment

\begin{tabular}{|c|c|c|}
\hline Type of creative device & Total number & $\%$ \\
\hline \multicolumn{3}{|c|}{ Literary devices } \\
\hline personification & 2 & 3.85 \\
\hline paronomasia & 4 & 7.69 \\
\hline metaphor & 13 & 25.00 \\
\hline metonymy & 6 & 11.54 \\
\hline oxymoron & 4 & 7.69 \\
\hline physical-synesthesia & 5 & 9.62 \\
\hline image & 13 & 25.00 \\
\hline peregrinism & 5 & 9.62 \\
\hline \multicolumn{3}{|c|}{ Formal devices } \\
\hline hyphenated compounds & 5 & 29.41 \\
\hline clipping & 4 & 23.53 \\
\hline acronym & 2 & 11.76 \\
\hline blending & 3 & 17.65 \\
\hline morphological imitatition & 3 & 17.65 \\
\hline
\end{tabular}

Table 2: Level of students' awareness of creative devices in the publicistic texts (\%)

\begin{tabular}{|l|c|c|}
\hline Type of creative device & $\begin{array}{l}\text { Number of creative } \\
\text { neologisms identified } \\
\text { by the students }\end{array}$ & \% \\
\hline \multicolumn{3}{|c|}{ Literary devices } \\
\hline personification & 1 & 50.00 \\
\hline paronomasia & 3 & 75.00 \\
\hline metaphor & 4 & 30.77 \\
\hline metonymy & 4 & 66.67 \\
\hline oxymoron & 3 & 75.00 \\
\hline physical-synesthesia & 3 & 60.00 \\
\hline image & 4 & 30.77 \\
\hline peregrinism & 2 & 40.00 \\
\hline & Formal devices \\
\hline hyphenated compounds & 4 & 80.00 \\
\hline clipping & 2 & 50.00 \\
\hline
\end{tabular}

XLinguae, Volume 12, Issue 4, October 2019, ISSN 1337-8384, eISSN 2453-711X 


\begin{tabular}{|l|c|c|}
\hline acronym & 2 & 100.00 \\
\hline blending & 3 & 100.00 \\
\hline morphological imitatition & 1 & 33.33 \\
\hline
\end{tabular}

The investigation of creative devices in the publicistic texts involved in the experiment has shown that metaphor and image have taken the leading positions among the literary devices with a proportion of $25 \%$ while personification, paronomasia and oxymoron are considered to be less frequent creative devices in publicistic texts accounting for 3.85\%, 7.69\%, 7.69\% correspondingly. As for the formal devices, hyphenated compounds have the greatest predominance, with a rate of $29.41 \%$ followed by clipping $(23.53 \%)$. The least frequent device is an acronym $(11.76 \%)$, though the difference in the percentage of the most and the least frequently used devices is not significant. It corresponds to $17.65 \%$. It can be observed that the proportion of literary creative devices in the publicistic texts involved in the experiment is rather unstable in comparison to the use of formal devices. Although the corpus study is not very big, this trend is quite visible.

The experiment has also revealed that the level of students' awareness of literary creative devices that are less frequently used in the publicistic texts is high: personification $-50 \%$, paronomasia $-75 \%$, and oxymoron $-75 \%$. The maximum percentage of formal creative devices has shown acronym and blending. It can be explained by the differences in perception of creative neologisms by the writers and readers, though this assumption requires further investigation.

\section{Conclusion}

In this study, we have reviewed a definition of the creative neologism through the concepts of neology and creativity, identified and extracted creative neologisms from the publicistic texts, analyzed a typology of creative neologisms proposed by Sánchez (2016), and carried out an experiment revealing the level of students' awareness of creative neologisms in the publicistic texts. Our findings suggest that the percentage of literary creative devices in the newspaper articles involved in the experiment is rather unstable as compared with the formal ones. Though the corpus study is limited, this trend is quite obvious. The experiment has also shown that the students better recognized literary creative devices, which are less frequently used in the publicistic texts, which can be seen in the differences in perception of creative neologisms by the publicists and readership, though this assumption needs further research. This study aimed to shed some light on the creative neologisms used in the publicistic texts, with the final objective of serving as a reference for future investigation and professional purposes.

\section{Acknowledgments}

1.The work is performed according to the Program of Development of Financial University under the Government of the Russian Federation for 2020.

2.The work is performed according to the Russian Government Program of Competitive Growth of Kazan Federal University.

3.The publication has been prepared with the support of the "RUDN University Program 5-100".

4. The work is performed according to the project of improving competitiveness of the leading Russian universities among the leading world scientific education centers "5100 "of First Moscow State Medical University. 


\section{Bibliographic references}

AKHMANOVA, O.S. 2004. Dictionary of linguistic terms. 2nd ed., Erased. Moscow: URSS: Editorial URSS. ISBN: 978-5-98993-133-0.

BELKOVA, E.A. 2018. Creative neologisms in modern English, American and Russian science fiction. Graduation thesis. Yekaterinburg. Available online: http://elar.uspu.ru/bitstream/uspu/9820/2/02Belkova2.pdf

CAMBRIDGE DICTIONARY. 2019. Available online: https://dictionary.cambridge.org

DZHABRAILOVA, V.S. - KALASHNIKOVA, N.V. 2018. On English Occasional New Words Translation into Russian, In: Collection of scientific articles. Student Research, pp.110-114. ISBN: 978-5-907068-91-9.

FELDMAN, N. I. 1957. "Okkasionalnye Slova i Leksikografiya (Nonce Words and Lexicography)”. In: Voprosy Yazykoznaniya (Questions of Linguistics), vol.4, pp. 64-73. ISSN: 0373-658X.

GAVRIKOVA, Yu.A. - DEMENT'EVA, K.S. 2017. The Structural Analysis of Occasional Compound Units. In: Modern Scientists, vol.6, pp. 124-127. ISSN: 25418459 (online).

INVESTOPEDIA, $2019 . \quad$ Available online: https://www.investopedia.com/terms/c/creativedestruction.asp

JESSOP, B. - KNIO, K. 2018. The Pedagogy of Economic, Political and Social Crises: Dynamics, Construal and Lessons. London: Routledge. ISBN: 9781315161587.

KADOCH, M. 2013. Neologisms in British Newspapers. Thesis. Available online: https://theses.cz/id/wt9s01/Michal_Kadoch_Neologisms_in_British_Newspapers.pdf KLAMER, A. - LEONARD, T.C. 1994. So What's an Economic Metaphor? In: P. Mirowski ed. Natural Images in Economic Thought: "Markets Read in Tooth and Claw", pp. 20-51. Cambridge: Cambridge University Press. ISBN 978-0-521-443210

KOMLEVA, M. N. 2013. An occasional word in the language of print media of recent times: models and functions. Theses for the humanities. Available online: http://cheloveknauka.com/okkazionalnoe-slovo-v-yazyke-pechatnyh-smi-noveyshegovremeni-modeli-i-funktsii\#ixzz5vpHSZ7Jj

KOMLEVA, M. N. 2013. Creative neologisms' Formation and Characteristics (based on research of newspaper headlines). In: Scientific opinion, n.3, pp. 51-55. ISSN: 2222-4378.

KOSTOMAROV, V. G. 1994. The language taste of the era. Moscow: Pedagogicspress, 247 p. ISBN: 5-7155-0689-1.

KRYSIN, L.P. 2008. Defining dictionary of foreign words. Moscow: Eksmo. Available online: http://slovari.yandex.ru.

MACMILLAN DICTIONARY, 2009-2019. Available online: https://www.macmillandictionary.com/buzzword/recent.html

MERRIAM-WEBSTER. 2019. Available online: https://www.merriam-webster.com POPOVA, T.V. 2005. Russian Neology and Neography. Publishing house GOU-VPO UGTU-UPI, Yekaterinburg. Available online: https://study.urfu.ru/Aid/Publication/174/1/Popova.pdf

RADBIL, T.B. 2006. Linguistic Anomalies in a Literary Text: Dis. Dr. filol. Sciences: Moscow: MPGU. Available online: http://cheloveknauka.com/yazykovye-anomalii-vhudozhestvennom-tekste

RAITSKAYA, L.K. 2007. The main trends in the formation of neologisms in the modern economic text // Philological Sciences in MGIMO: collection of scientific. labor. No. 25 (40) / MGIMO (University) of the Ministry of Foreign Affairs of Russia; open ed. G.I. Gladkov. - M.: MGIMO-University, pp. 95-103. ISBN: 978-59228-0266-6.

XLinguae, Volume 12, Issue 4, October 2019, ISSN 1337-8384, eISSN 2453-711X 
SAMYLICHEVA, N.A. 2011. Occasional words as a means of expressing a newspaper text: on the material of the Nizhny Novgorod media. (Okkazional'nyye slova kak sredstvo ekspressivizatsii gazetnogo teksta: na materiale nizhegorodskikh SMI). PhD Thesis Abstract. Nizhny Novgorod. 25p. Available online: https://www.dissercat.com/content/okkazionalnye-slova-kak-sredstvo-

ekspressivizatsii-gazetnogo-teksta/read

SANCHEZ, B. N. 2016. The translation of creative neologisms in economic discourse about the global crisis. Available online: https://www.researchgate.net/publication/325384946

SELIVANOVA, O. O. 2010. Linguistic Encyclopedia. Poltava: Dovkillya. K. 844 p. SHAPOCHKIN, E.A. - BUTENKO, L.N. 2011. Detection of Requirements for Models of Knowledge Representation for the Domain of Creative Neologisms Translation. In: Advances in current natural sciences, n.4, pp. 163-164. ISSN: 16817494.

SHCHUKIN, A.N. 2007. Linguodidactic encyclopedic dictionary. Moscow: Astrel: AST: Khranitel. ISBN: 5-17-039816-6

THE GUARDIAN. Available online: https://www.theguardian.com THE INDEPENDENT Available online: https://www.independent.co.uk URBAN DICTIONARY. 2018. Available online: https://www.urbandictionary.com USHAKOV, D.N. 1935-1940. Explanatory Dictionary of the Russian Language/ Moscow: State Institute "Soviet encyclopedia"; OGIZ; State publishing house of foreign and national words, 1935-1940. (Four volumes). Available online: http://febweb.ru/feb/ushakov/ush-abc/14/us252504.htm?cmd=0\&istext=1 ISBN: 5864554065

VERDEGAL, J. 2003. La traducción de neologismos [The Translation of Neologisms]. In: Puntoycoma, n. 83, pp. 7 - 20. ISSN: 1886-8193.

VINOGRADOV, V. S. 2004.Translation: general and lexical issues: a textbook. 2nd ed., Revised. Moscow: KDU. ISBN:5-98227-018-0.

WIKTIONARY. Available

https://en.wiktionary.org/wiki/Wiktionary:Main_Page

YURCHENKO, T.G. 2005. The Problem of Occasional Words from the Point of View of Their Noveity and Individual-Author's Belonging. In: Visnyk of Zaporizhzhya National University, n.2, pp. 199-205. ISSN: 2414-9594.

ZAWADA, B. 2005. Linguistic Creativity and Mental Representation with Reference to Intercategorial Polysemy. PhD Thesis. University of South Africa. Available online:

https://pdfs.semanticscholar.org/c5f7/9b4e07242991724e3aa27c2c1b0f0851542e.pdf ZEMSKAYA, E. A. 1992. Word-formation as an activity. Moscow: Nauka. ISBN: 502-011082-5.

ZEMSKAYA, E.A. 1972. Occasional and potential words in Russian word formation. Actual problems of Russian word-formation. Samarkand: Samarkand State Univ. Publ. pp. 19-28.

Words: 4993

Characters: 34771 (19,32 standard pages)

Assoc. Prof. Olga A. Kalugina

Department of Foreign Languages

Financial University under the Government of the Russian Federation

49 Leningradsky prospect

125993 Moscow

Russia

kaluginaruc@mail.ru 
Assoc. Prof. Dinara G. Vasbieva, PhD

Department of Foreign Languages

Financial University under the Government of the Russian Federation

49 Leningradsky prospect

125993 Moscow

Russia

dinara-va@list.ru

Prof. Roza A. Valeeva, Doctor of Education

Institute of Psychology and Education

Kazan (Volga region) Federal University

18 Kremlyovskaya Street

420008 Kazan

Russia

valeykin@yandex.ru

Assoc. Prof. Elena V. Maystrovich

1) Scientific and Educational Center "Legal Research"

Peoples' Friendship University of Russia (RUDN University)

Miklukho-Maklaya Str. 6

117198, Moscow

Russia

2) Department of Culture and Arts

Stolypin International Institute of Informatization and Public Administration 11/2 Malaya Semyonovskaya Str.

107023, Moscow

Russia

elena.maystrovich@yandex.ru

Assoc. Prof. Olga V. Pashanova, PhD

Department of Organization and Economics of Pharmacy

I.M. Sechenov First Moscow State Medical University (Sechenov University)

8 Trubetskaya Street

119991, Moscow

Russia

ov-pashanova@yandex.ru 